\title{
The Importance of Critical Thinking on Teaching Learning Process
}

\author{
Howaida Awad Elballal Shamboul \\ English Language Department, Taif University, Taif, Saudi Arabia \\ Email: howida-shamboul@hotmail.com
}

How to cite this paper: Shamboul, H. A. E. (2022). The Importance of Critical Thinking on Teaching Learning Process. Open Journal of Social Sciences, 10, 29-35. https://doi.org/10.4236/jss.2022.101003

Received: December 2, 2021

Accepted: January 7, 2022

Published: January 10, 2022

Copyright $\odot 2022$ by author(s) and Scientific Research Publishing Inc. This work is licensed under the Creative Commons Attribution International License (CC BY 4.0).

http://creativecommons.org/licenses/by/4.0/

\begin{abstract}
Critical Thinking plays a great role in teaching-learning process, so this paper aims to prepare students to think critically by applying critical thinking to the students' presentation. From the beginning of the term, I gave a clear picture of the course (Travel Literature) to students and I equipped them with thoughts to be skillful during our lectures. Students apply critical thinking to the novel of Robinson Crusoe with skillful performance and I evaluate their presentation with the word ACTION due to the activity in this purpose. I found that students collaborated, shared thoughts, interesting in their presentations, were creative, precise, very organized and active. I recommended applying critical thinking in the classroom throughout activities and setting intellectual standards.
\end{abstract}

\section{Keywords}

Critical Thinking, Thought, Action

\section{Introduction}

The importance of critical thinking comes from that critical thinking is a domain-general thinking skill and promotes creativity through self-reflection and justifies our ways of life and opinions. In addition to that, critical thinking improves language and presentation skills by knowing how to think clearly and systematically (University of the People, 2021).

In critical thinking, the knowledge is not enough, you should have the competency to analyze data and real issues in a manner that makes sense of the information you have (Wilson, 2017). This competency will lead you to ask the right question that guides you to deeper understanding and more meaningful connections between people (Rayan, 2017). 
The failure to think clearly or what experts call a "cognitive error" is a systematic deviation from logic, optimum rational, reasonable thought and behavior (Dobelli, 2013). This error can be averted by knowing how your brain works and consciously trying some of the techniques that drive you to acquire a variety of useful mental skills (Albrecht, 2009). Critical thinking is one of the most important cognitive skills that one can develop through the practice of thoughtful thinking and it contributes to making a positive change in an individual's life on both the professional and personal levels (Sutour, 2020).

In the twentieth century, learning to think is the fundamental objective of education (Dewey, 1939). The emphasis has been shifted from imparting information and content to the learners, to enhancing their thinking skills. Education systems almost all over the world are shifting their focus to improving learners' higher mental processes comprising critical thinking and problem-solving (Ashraah et al., 2012).

\section{Definition}

Critical thinking is not the same as disagreement. There is a considerable difference between disagreement and critical thinking. A disagreement is a clash of views. When you assert an opinion and I deny it or state an opposing opinion, we are in disagreement but not thinking critically. Critical Thinking is interested in the pros and cons (Barry, 1984).

Critical thinking does not aim to embarrass or humiliate, and it does not allow you to dominate somebody else. Thinking critically does give one a kind of power. After all, if you can be determined and assess the reasons for a belief if you can make a discussion more enlightening, you stand a good chance of getting to the nub of an issue, of solving problems, of gaining greater control over your life, of attaining truth. In short, critical thinking does help you gain knowledge, and knowledge, as commonly observed, is a kind of power (Barry, 1984).

Critical thinking does not entail nitpicking. Nitpicking is one who is unduly preoccupied with minutiae. The critical thinker, by contrast, is concerned with substance, not trivia. Yes, thinking critically requires analysis, which in turn calls for attention to detail. But the details the critical thinker attends to are both relevant to the position and significant in its support. They are not side or trivial issues (Barry, 1984).

Critical thinking does require information and creativity. Some view critical thinking as a dry dust exercise in analysis. Although it is true that critical thinking requires painstaking analysis, it also can call for creative thinking. While the critical and creative aspects of thinking can be distinguished, they cannot be easily separated. The effective critical thinker inevitably is creative (Barry, 1984).

Critical thinking can be applied not only to the beliefs and positions of others but also to our own. Although it is true that you can apply critical thinking scalpel-like to dissect the claims you encounter, its application is by no mass confined to the views of others (Barry, 1984). 


\section{Literature Review}

The Elements of thought are one of the domains of critical thinking in addition to the abilities, affective dimensions and intellectual standards. The basic conditions implicit whenever we gather, conceptualize, apply, analyze, synthesize, or evaluate information - the elements of thought-follows: purpose, goal or end in view, question at issue or problem to be solved, point of view, frame of reference, the empirical dimension of reasoning, the conceptual dimension of reasoning, assumptions, implications and consequences and inferences (Paul, 1995).

The elements of thought do not exist in isolation from one another, nor-more importantly, for the concept of an assessment procedure-do they exist outside a particular context of application (Paul, 1995). In affective dimensions, higher-order thinking requires more than order thinking skills. Critical thinking-in a substantive sense-includes more than abilities. The concept also includes, in a crucial way, certain attitudes, dispositions, passions and traits of mind (Paul, 1995).

In any domain where assessment is taking place, there are standards implicit in that assessment. Intellectual standards that apply to thinking in every subject were shown in Table 1. The process of learning to teach so as to foster critical thinking is the very process by means which one establishes intellectual standards for assessing thinking and by extension for assessing instruction itself. Such standards are more useful if they are made explicit-to the students who are taking the test, to those doing the assessing and to classroom teachers (Paul, 1995).

Table 1. Intellectual standards that apply to thinking in every subject (Paul, 1995).

\begin{tabular}{ccc}
\hline Thinking that is: & vs & Thinking that is: \\
\hline Clear & vs & Unclear \\
Precise & vs & Imprecise \\
Specific & vs & Vague \\
Accurate & vs & Inaccurate \\
Relevant & vs & Irrelevant \\
Plausible & vs & Implausible \\
Consistent & vs & Inconsistent \\
Logical & vs & Illogical \\
Deep & vs & Superficial \\
Broad & vs & Narrow \\
Complete & vs & Incomplete \\
Significant & vs & Trivial \\
Adequate (for purpose) & vs & Inadequate \\
Fair & vs & Biased or One-Sided \\
\hline
\end{tabular}


One of the reasons that instructors tend to overemphasize "coverage" over "engaged thinking" is that they do not fully appreciate the role of questions in teaching content. Consequently, they assume that answers can be taught separate from questions. Indeed, so buried are questions in established instruction that the fact that all assertions-all statements that this or that is so-are implicit answers to questions is virtually never recognized (Elder \& Paul, 1998). Thinking is not driven by answers but by questions. Feeding students endless content to remember (that is, declarative sentences or "facts" to remember), most students ask virtually none of these thought-stimulating types of questions (Elder \& Paul, 1998).

The art of Socratic questioning is important for the critical thinker because the art of questioning is important to excellence of thought. What the word "Socratic" adds is systematic, depth and a keen interest in assessing the truth or plausibility of things (Elder \& Paul, 1998). The goal of critical thinking is to establish a disciplined "executive" level of thinking to our thinking, a powerful inner voice of reason, to monitor, assess and reconstitute-in a more rational direction-our thinking, feeling and action. Socratic discussion cultivates that inner voice by providing a public model for it (Elder \& Paul, 1998).

\section{Methodology}

The course examines the forms and functions of travel literature as a genre through both fictional and non-fictional texts. Students would be exposed to critical understanding of a selection of works related to travel writing.

From the beginning of semester, I explained to my student's course plan and specifications (objectives, content, instruction, activities, assessment tasks and learning resources) so the mental map is clear for them. As teachers, we address minds when we bombard our students with critical thinking, so their thinking becomes rational, enlightening their insight into the future, not only for a moment on inside the classroom but also they become good citizens of their countries. Providing students with a deeper understanding of the cognitive content in the academic subject and continued revitalization of the academic subject, which make the study subjects more of their lives.

After many lectures as scheduled, I prepared my students for the presentation by explaining our goals of it. Not only to present in front of audiences but also we want to show the ability to produce language, understand our content, collaborate with others, expand our knowledge of the outside world and prepare them emotionally and psychically by taking time to organize their thoughts and look forward to presenting in front of the class.

I divided the students into groups; each group consisted of different personalities and skills. Then I listed many topics related to the course content and each group chooses an interesting topic. The group discusses the topic with each other's in the class and I turn among each group to hear their discussion and help them before presentation day. 


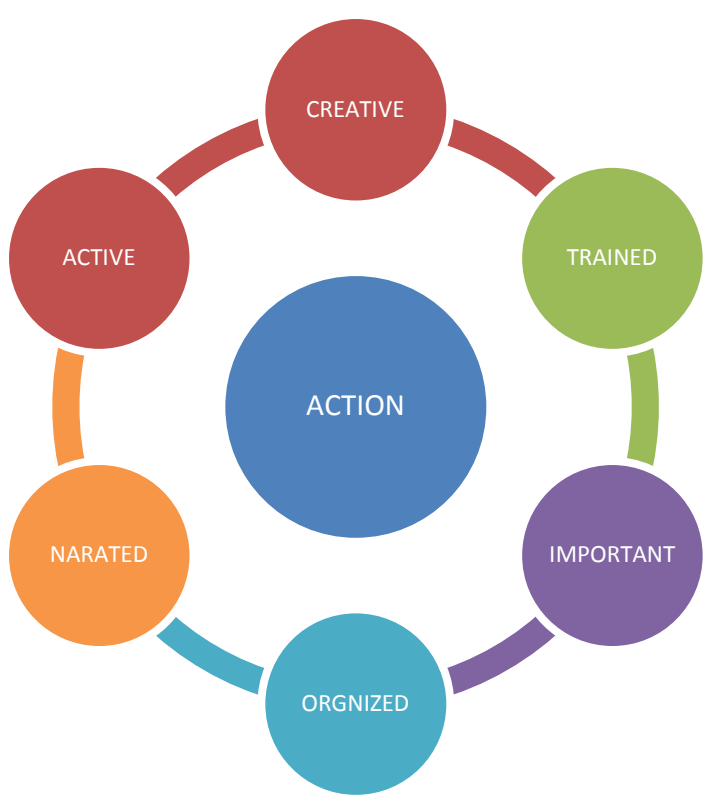

Figure 1. Parameters that measure the performance of students.

\section{Results and Discussion}

At the end of the presentation, my students achieved the framework that I put according to my great expectations from my students' actions. I put the word ACTION to measure my students' performance in the class and it stands for Active, Creative, Trained, Importance, Organized and Narrated and all these combine critical thinking of successful presentation (Figure 1).

Active: students show great activity during the presentation in an energetic and interesting manner.

Creative: students seek things from the environment, e.g. plants and related them to that area of Novel of Robinson Crusoe and they created quotations aid by Robinson Crusoe in the imaginative picture too.

Trained: students displayed material of the Robinson Crusoe novel in an artistic way and that showed they prepared themselves well.

Importance: students introduced a significant picture of the Robinson Crusoe novel.

Organized: students presented their work in an organized, neat manner and distributed their roles in an attractive way.

Narrated: students analyzed their thought of the novel in a good, clear voice and narrate it with pleasure.

\section{Conclusion}

Critical thinking is very important in the teaching-learning process for that we need to bring it to our classroom by practicing and practicing it throughout activities such as presentations and by putting intellectual standards. When we support our students with exposure to intellectual ideas, so our students get creative and we will enhance learning outcomes. 
When we apply critical thinking in our subject we will see vivid pictures from our students and they acquire skills (active, creative, trained, organized, narrated) not only in the classroom but also in their life.

Figures below are about Robinson Crusoe Presentation.
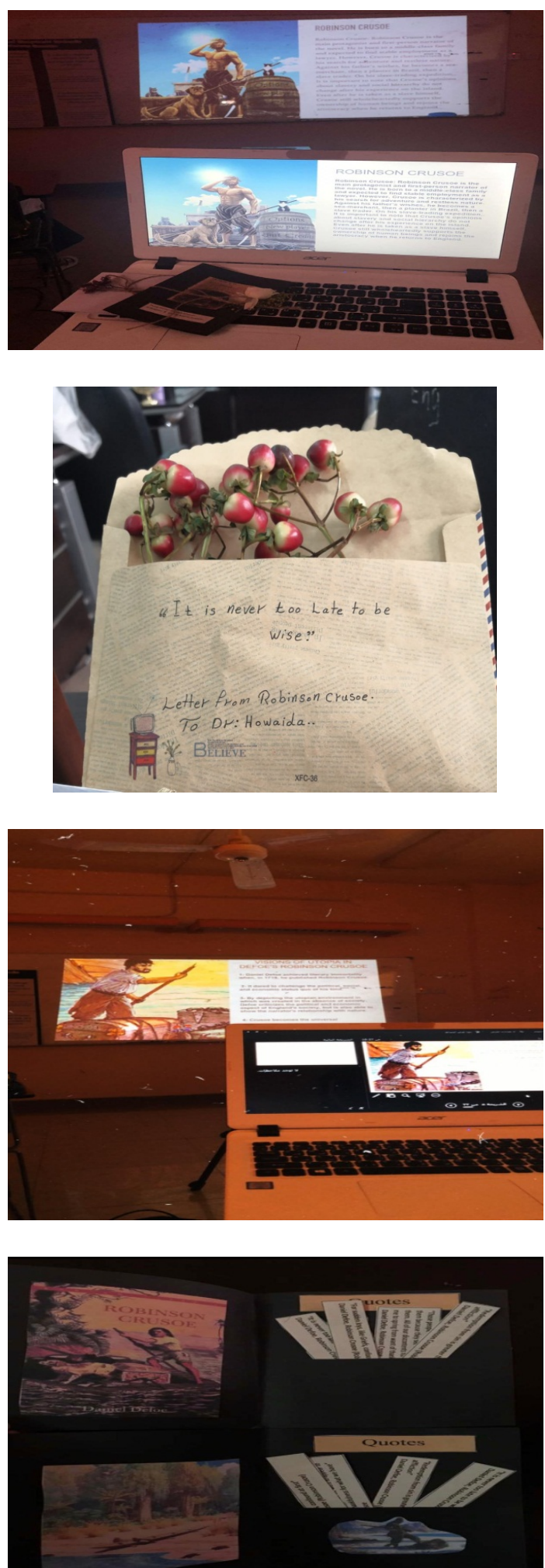


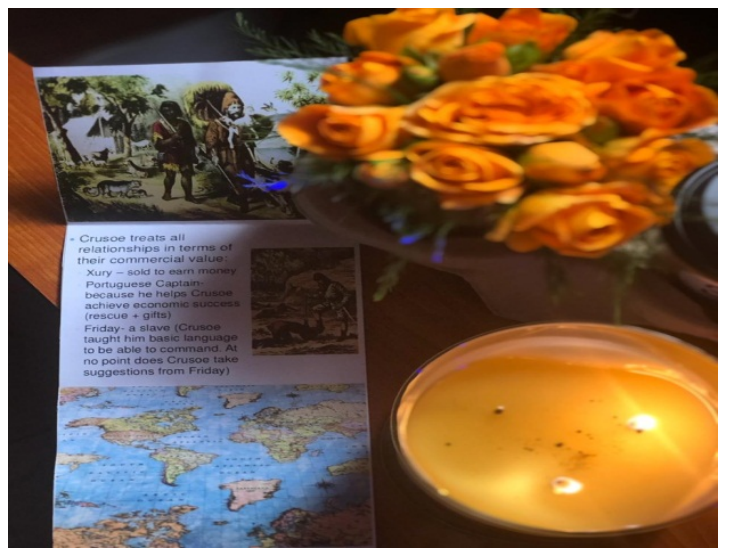

\section{Acknowledgements}

Thanks the American English Institute University of Oregon for the opportunity to attend a critical thinking E-course, and special thanks to instructor/Agnieszka Alboszta for her great helps during the critical thinking E-course.

\section{Conflicts of Interest}

The author declares no conflicts of interest regarding the publication of this paper.

\section{References}

Albrecht, K. (2009). Brain Power: Learn to Improve Thinking Skills. Touchstone.

Ashraah, M. M., Al-Nabrawi, M. I., Shdeifat, S., \& Al Ali, M. T. F. (2012). Critical Thinking Skills for Islamic Education Teachers: A Study of Teachers' Perceptions. International Journal of Academic Research, 4, 70-74.

Barry, V. E. (1984). Invitation to Critical Thinking. CBS College.

Dewey, J. (1939). Experience and Education. Colliner Books.

Dobelli, R. (2013). The Art of Thinking (1st ed.). HarperCollins.

Elder, L., \& Paul, R. (1998). The Role of Socratic Questioning in Thinking, Teaching and Learning. The Clearing House: A Journal of Educational Strategies, Issues and Ideas, 71, 297-301. https://doi.org/10.1080/00098659809602729

Paul, R. (1995). The Four Domains of Critical Thinking. In J. Willsen, \& A. J. A. Binker (Eds.), Critical Thinking: How to Prepare Students for a Rapidly Changing World (pp. 123-132). Foundation for Critical Thinking.

Rayan, J. E. (2017). Wait, What? And Life's Other Essential Question (1st ed.). Harper Collins.

Sutour, K. (2020, December 10). The Importance of Critical Thinking.

University of the People (2021). Why Is Critical Thinking Important? A Survival Guide. https://www.uopeople.edu/blog/why-is-critical-thinking-important/

Wilson, J. (2017). Critical Thinking: A Beginner's Guide to Critical Thinking, Better Decision Making and Problem Solving! CreateSpace Independent Publishing Platform. 